\title{
REDAKSIONEEL
}

\section{HEENGAAN DR. K. S. v. W. DE VRIES}

DIE heengaan van dr. K. S. v. W. de Vries aan 'n koronêre trombose op 10 Oktober was nie alleen onverwags nie, maar 'n slag wat 'n plek leeglaat wat na die mens gesproke nie weer gevul sal kan word nie. Ons innige deelneming en meegevoel gaan uit na sy moeder, eggenote, kinders, kleinkinders en familie, ds. Kotie de Jager en die kerk van Pretoria-Oos, in besonder die groot getal bejaardes wat in die onderneminge van die Geref. Stigting in besonder na hom opgesien het as hulle weldoener, biegvader, vertrooster, raadsman en predikant.

In die verskillende fasette van ons Gereformeerde kerkverband het hy 'n unieke, verantwoordelike, rigtinggewende en leidende rol gespeel. Soos hy in sy artikel oor „Barmhartigheid” in die vorige uitgawe nog bepleit het, het hy vanuit sy prinsipiële en geloofsoortuiging prontuit sy lig laat skyn op politieke en kulturele sake van die dag.

Dr. K. S. v. W. de Vries was ook die vader van die GTV, sy konstitusie, sy werkswyse en sy blad, In die Skriflig. Dit het vir hom nie om die institusionele en vorm gegaan nie. Hy was in murg en been predikant wat 'n getuienis na buite wou laat uitgaan. Teologie was vir hom nie doel op sigself nie, maar middel om die heerskappy van Jesus Christus, d.w.s. die koninkryk van God, uit te brei. Hoe min teologie of sy onderneminge en moeite vir hom op homself gerig was, blyk daaruit dat toe hy as teologiese professor beroep was, hy dit bedank het om met sy wydvertakte bediening en dienslewering in Pretoria-Oos voort te gaan.

Almal wat die Gereformeerde teologie in Suid-Afrika lief het, moet erken dat hy vir ons 'n baanbreker was. Hy het koers gewys, voor geloop en voor gedoen.

Hy was so dikwels op sy kenmerkende fyn, netjiese manier namens die Geref. Stigting gasheer van die Jaarvergadering en maandeliks van die tak van Pretoria. Dit is byna simbolies dat hy in sy sterfjaar in Pretoria-Oos op sy laaste Jaarvergadering, ook op unieke humoristiese wyse 'n doodernstige referaat oor die aktualiteit van kerk-wees vandag gelewer het. Dit is in die vorige uitgawe gepubliseer. Hy het dit nooit in druk kon lees nie.

'n Mens sou geensins oordryf wanneer jy sou sê dat die sterkste boodskap wat dr. K. S. v. W. de Vries met sy lewe en nou nadat hy dood is tot ons rig, 'n kragtige oproep is om die waarheid vas te gryp dat God ons lief het in Christus en ons gered het tot diens 
op elke terrein van die lewe. Daarom was hy 'n sorgsame vader en eggenoot, ' $n$ liefdevolle prediker, 'n werker in alle geledinge van die kerk, 'n Afrikaanse patriot en kritiese begeleider van die politiek van die dag, waker oor die kultuur as lid van die Appēlraad op Publikasies, bewoë diaken wat hom die nood van die bejaarde as sy eie aangetrek het, vriend en gasheer van die jeug.

Hy was in menige opsig uniek - in sy prinsipiële grepe, sy logiese en helder betoë, die verrassende met wat hy aangepak en deurgevoer het. Hy was daarom dikwels ook omstrede. Hy het nie bloot gefunksioneer in 'n struktuur en sisteem nie. Hy het as mens 'n roeping van God geken en hy het dit uitgevoer. Daarom was hy dikwels onkonvensioneel. Juis daarin lê egter die grootheid van sy diens. Hy het nie in diens van strukture, liggame, instellings, patrone en werkswyses gestaan nie. Hy het strukture, liggame en al die ander gebruik om as mens die lig van sy gereformeerde geloof en kennis uit te dra tot heil van sy naaste en tot eer van God.

In die Skriflig eer die nagedagtenis van 'n besondere broeder, 'n gawe en begaafde van die Here, wat ons vooruit gegaan het. 